\title{
Beyoncé, Black Motherhood, and the Return of Wrenching Times
}

\author{
Michelle S. Hite ${ }^{1 *}$
}

Published: September 10, 2019

\begin{abstract}
This article contends that Beyoncé Knowles stages several spectacles in tribute to the mothers of slain Black sons as an homage to Mamie Till-Mobley, the mother of 14-year-old Emmett Till, and interrogates the role Beyoncé plays in supporting Black mothers in rescuing their dead children's fate from the banlieues of racist logic, and thus the normalising of Black children dying out of sequence. Knowles's effectiveness results from the appeals she makes to Black collective memory of the staggering offence the U.S. nation-state has perpetuated against Black children. This article asserts that the relationship Knowles has forged with highly visible Black mothers of murdered sons enacts what Daphne A. Brooks has defined as 'Black feminist surrogation,' which is 'an embodied performance that recycles palpable forms of Black female sociopolitical grief and loss as well as spirited dissent and dissonance.' To this end, Knowles, recuperates Mrs. Till-Mobley as an icon of grief and in doing so, helps to define the Mamie Till-Mobley narrative of Black motherhood as that which expresses the will to overcome the continued denigration of the integrity of Black parenting as well as the sustained assault against Black mothers' pursuit of justice for their children since 2012.
\end{abstract}

Keywords: celebrity, Beyoncé, Black Motherhood, Emmett Till, Mamie Till-Mobley

\section{INTRODUCTION}

Scholar Daphne A. Brooks draws on a reading of African American pop stars Beyoncé Knowles and Mary J. Blige to define 'Black feminist surrogation' as 'an embodied performance that recycles palpable forms of sociopolitical grief and loss as well as spirited dissent and dissonance' (Brooks, 2008: 180). For Brooks, such surrogacy is effected through singing, which 'marks a new era of protest singing that sonically resists, revises, and reinvents the politics of Black female hypervisibility in the American cultural imaginary' (Brooks, 2008: 180). This article extends Brooks's theory by using Beyoncé's political interventions following the devastation wrought by Hurricane Katrina in 2005, to argue that the singer has continued to deepen and expand the work of recycling 'palpable forms of Black female sociopolitical grief and loss' through the lens of Black motherhood. Thus, alongside the resistance, revision, and reinvention that Brooks first identified, Beyoncé now recuperates a specific narrative of Black maternal grief by recalling the experience and suffering of iconic Black activist, Mamie TillMobley.

Mamie Till-Mobley emerged as a critical voice in American culture after her 14-year-old son, Emmett Till, was found dead in the Tallahatchie River on August 28, 1955. Young Till left his home in Chicago, Illinois to visit relatives in Money, Mississippi. Emmett had very little first-hand experience of either the customs or the laws stipulating racial segregation that were strictly enforced in the American South. His ignorance proved tragic when he entered Bryant's Grocery and Meat Market and fatefully encountered Carolyn Bryant, the storeowner's wife. Mrs. Bryant claimed that while they were alone together in the store, Emmett accosted her. Acting on this claim, her husband Roy Bryant and his half-brother, J.W. Milam stunned Emmett's uncle Moses Wright and the other members of his home when they showed up late at night armed and demanding to see the boy who had dishonoured Mrs. Bryant. Fearing the harm that could come to his nephew, Wright pleaded with Bryant and Milam to take him instead but only Emmett would satisfy the pair. Mrs. Till-Mobley was soon notified that her son had been kidnapped at gunpoint. 
Ruth Feldstein's scholarship on Mrs. Till-Mobley provides essential reading on her importance as an African American woman, mother, and principal author of the politicisation of Emmett's murder during the 1950s. ${ }^{1}$ Examining representations of Mrs. Till-Mobley in the White and Black news print media, Feldstein demonstrates that 'motherhood itself was a battleground on which the meaning of [Emmett] Till's death was fought' (Feldstein, 2000: 265). Using Mamie Till-Mobley as a prism, Feldstein emphasizes the ways that race problematizes the ways that motherhood had been established as a site for claiming moral authority over children, for identifying their remains, evoking sympathy for their loss, or seeking justice in their names. Such an insight regarding race and motherhood matters, given that Black mothers have repeatedly stood as witnesses to lethal, race-based violence. As Karla Holloway contends, the 'death of children should be unexpected events in the life-death cycle' and yet Black children's experience of meeting an untimely death in the United States 'had become familiar — and even anticipated' (Holloway, 2003: 131); this fact remains. Therefore, this article seeks to expand the scope of Mrs. TillMobley's role in politicising her son's death, through a consideration of Beyoncé's role in staging 'Black feminist surrogation' and so demanding justice for murdered Black children through a revised and stylised presentation of their mothers.

Thus, this article locates its interest in the role that Black mothers have played in rescuing their dead children's fate from the banlieues of racist logic and the normalising of Black children dying out of sequence. ${ }^{2}$ I contend that while the racist and patriarchal logic that denigrated Mamie Till-Mobley and sought to undermine her moral authority as a mother surely proved challenging, she has emerged the victor on the battleground of memory. So, as Mississippi tried to erase the brutal imprint of the marks it left on young Emmett's body by first attempting to bury him and then claiming he simply walked away (Whitaker 1988: 22, 41); as media reports tried to ease the horror of this crime by making the boy a monster and his living accuser, Carolyn Bryant, an ethereal beauty (Tyson, 2017: 1), Black people who saw that boy laying brutalised and bloated in a glass-top casket or pictured ugly in Jet magazine remembered what they saw and recalled the courage of the woman who extended them their invitation to look. As Ralph Ellison posited about Black American memory:

Negro American consciousness is not a product (as so often seems true of so many American groups) of a will to historical forgetfulness. It is a product of our memory, sustained and constantly reinforced by events, by our watchful waiting, and by our hopeful suspension of final judgment also to the meaning of our grievances. (1995: 124)

Since 1955, the mobilising of Black motherhood as a marker of righteousness and fitness for exposing crimes against Black children has been an exercise in Black collective memory. To that end, this article expands Brooks's articulation of 'Black feminist surrogation' through the figure and deliberate efforts of Beyoncé to consider her current recuperation of Mamie Till-Mobley as an icon of grief. I assert that Beyoncé helps to define the Mamie Till-Mobley narrative of Black motherhood as that which expresses the will to overcome the continued denigration of the integrity of Black parenting (especially at the site of grief), the legitimacy of Black maternal grief, and the sustained assault against Black mothers' pursuit of justice for their children since 2012.

\section{AESTHETICS OF GRIEF}

The invitation Beyoncé extended to four Black mothers of slain sons to attend the MTV Video Music Awards (VMA) at Madison Square Garden on August 28, 2016 sets in relief her clear recognition of the role that Black mothers have historically played in demanding that the world look at the brutal, if not lethal, handling of Black children at the hands of the state. Thus, 58-years to the day that Emmett Till was killed and thus in the aftermath of his mother's demand for witnesses to look upon the gruesome mess white supremacy made of her child, Beyoncé invited a new generation of Black mothers whose children have been added to the nation's dishonoured

\footnotetext{
${ }^{1}$ As this article engages extensively with the Jim Crow past that described race relations in the United States when Emmett Till was murdered, and as his mother pursued justice for him, it insists on acknowledging the aspects of respectability that mattered to its key subjects. To that end, I refer to Mamie Till-Mobley as Mrs. Till-Mobley throughout the article as Black women were routinely denied courtesy titles at a time when they were commonly used in referring to or in addressing adults. In fact, Black women often used their husbands' first and last names along with a courtesy title to prevent white people from addressing them using their first names and so in a way that suggests familiarity. Spike Lee provides an excellent case of this in 4 Little Girls (1997), his documentary film about the bombing of the 16th Street Baptist Church on September 15, 1963. In the film, Mrs. McNair rails against a white nurse in the morgue who insists on calling her 'Maxine.' In her grief, Mrs. McNair corrects the woman's racist presumption and boldly identifies herself as 'Mrs. Chris McNair.' ${ }^{2}$ In referring to the 'banlieues of racist logic' I aim to draw attention to the French term for the circle of suburbs surrounding a city, which have become predominantly places of high rise public housing where ethnic minorities, and the poor, have been placed. These suburbs, often the place of public riots, have seen state violence against racial and ethnic citizens, including police dragging pregnant Black women on the ground, sometimes with their bare backed infant children on the cement in order to stop them from protesting their eviction from apartments in the Seine-Saint-Denis suburb of Paris in 2010. See further: 'Video of Forced eviction in Paris Suburb Prompts Shock,' France 24. https://www.france24.com/en/20100730-video-forced-evacuation-paris-suburb-provokes-shock-tent-women-police-children
} 
roll to echo Mamie Till-Mobley's demand to let the people see it (quoted in Whitfield, 199123 ). Beyoncé's publicity website Beyoncé.com shows the singer's awareness of the VMAs coinciding with the date of Emmett Till's death; it features Moveon.org's, \#actnow4Trayvon, which frames its narrative between the death dates of both sons and in doing so it exemplifies the critically engaged memory that Ralph Ellison associates with Black American consciousness (1995: 124).

The explicit call for activism expressed in the online petition mirrors the political activism of previous generations in the wake of Emmett Till's murder. Thus, the message that Beyoncé posted on her website accepts the call to make Trayvon Martin's murder a rallying cry and her awards show guest list takes up that charge. Lezley McSpadden, Gwen Carr, Wanda Johnson, and Sybrina Fulton attended the 2016 VMAs as Beyoncé's guests. These mothers, like Mamie Till-Mobley before them, became recognizable through the deaths of their sons. Like Mrs. Till-Mobley, the mothers that invited as her guests made their critique of racism and power explicit. In previous generations, as seen through the lens of Mrs. Till-Mobley, civil rights groups like the NAACP extended the witness of a grieving mother to mobilize the public towards protest. Beyoncés online petition works in similar fashion. Thus, the message that Beyoncé posted on her website accepts the call to make Trayvon Martin's murder a rallying cry and her award's show guest list takes up that charge. Lezley McSpadden, Gwen Carr, Wanda Johnson, and Sybrina Fulton attended the 2016 VMAs as Beyoncé's guests. Each of their son's deaths have shaped the visual field of police brutality and racial violence that has led many to query the relationship between past atrocity and contemporary horror.

Cell phone video taken from citizen journalists, police dash-cam video, and public surveillance video have routinely captured instances of excessive force as well as lethal instances of police brutality being used against Black people since the death of Trayvon Martin and the exoneration of his killer, George Zimmerman, on July 13, 2013. These visual records document longstanding African American grievances concerning police brutality (Kelley, 2000: 24, 49). While the circulation of these visual records through social media has guaranteed a broader public audience beyond Black communities, the list of Black victims of police brutality continued to grow. In many communities across the United States outrage turned into protests.

One of the earliest protests occurred in New York on July 17, 2014 when cell phone video showed 43-year-old Eric Garner uttering "I can't breathe" eleven times while officer Daniel Pantaleo held him in an illegal chokehold (Lowery, 2019). Less than a month later, police officer Darren Wilson shot and killed 18-year-old Michael Brown on August 9, 2014 in Ferguson, Missouri. Wilson fired the first shots after alleging that the unarmed Brown attacked him through the window of his police SUV (Somashekhar and Kelly, 2014). According to Wilson, he fired the lethal shots at Brown because he felt threatened when the injured Brown initiated a forward motion that he interpreted as an aggressive charge (Somashekhar and Kelly, 2014). Making matters worse, the police left Brown's exposed, bullet riddled body in the middle of the street where he was shot for at least four hours (Bosman and Goldstein, 2014).

The scene of Brown's death provided an occasion for the mobilisation of grassroots activists who organised themselves through the lens of \#BlackLivesMatter, a hashtag which originated from a Facebook post that Alicia Garza made after the acquittal of George Zimmerman in 2013 (Cobb, 2016). Garza, Patrisse Cullors, and Opal Tometi drew on their skills as organisers and activists, their identity as queer women of colour, and their deep sadness and anger over the Zimmerman verdict to inform what became the Black Lives Matter movement (BLM). BLM draws on the rootedness of its membership in their own local communities to respond to and disrupt systemic violence against Black flourishing. BLM website frames its work as a movement through its "ideological and political intervention" (Herstory, n.d.). Brown's death carried the BLM message through the hashtag \#blacklivesmatter.

By the time Beyoncé appears at the VMAs with the mothers of the victims of police brutality and vigilante violence, \#blacklivesmatter identified and reclaimed even the dead who came before its genesis as falling within its scope. For example, cell phone video captured on the Bay Area Rapid Transit platform on January 1, 2009 showed police officer Johannes Mehserle shooting Oscar Grant III while he lay prone with his hands tied behind his back (McKinley, 2010). The outrage and protests following Mehserle's conviction on a lesser charge matched the outcry at the sense of injustice experienced following similar verdicts in the BLM era.

Contemporary social media commentary, popular news articles, and classroom discussions have invested time and attention on Michael Brown's prone body, Oscar Grant's open execution, Eric Garner's pleas to breathe, and Trayvon Martin's ostensibly ominous hooded sweatshirt; these separate representations are often associated with the powerful symbol of Emmett Till's brutalised face. Mainstream media has voiced the association between past and present horrors in thoughtful editorials from artists, journalists, and scholars including Claudia Rankine, Isabel Wilkerson, and Elijah Anderson. Wilkerson's reflections on Tamir Rice, the 12-year-old victim of Cleveland Police Officer Timothy Loehmann's quick trigger, destabilises certain claims about the progress the nation has made towards racial justice. In 2014, Loehmann shot Rice within seconds of arriving on the scene of the boy playing with a toy gun and did not stand trial for his actions. As Wilkerson notes in her New York Times article, 'Emmett 
'Till's killers were acquitted by an all-white jury, but at least they had gone to trial,' (Wilkerson, 2016) and thus the boy who symbolises the impoverishment of criminal justice for Black Americans appears the beneficiary of a largess compared to Black Americans killed by police shootings during the 21st century. Anderson's article for the Washington Monthly (Anderson, 2013) accepts that there are similarities between Till and Martin, but urges greater consideration for the nuances of contemporary articulations of race thus writing that, 'these killings must be understood as the result of very different strains of racial tensions in America' (Anderson, 2013). According to Anderson, Martin lived during a time that evidenced great tension between the extreme displacement of Black Americans into urban ghettos and the incorporation of the largest Black middle class in American history. For him, racism has greater complexity today than in Till's time. In the face of what might be contemporary nuance, the fact remains, for Rankine, that a fundamental experience of Black life in America has long been a permanent 'condition of mourning' within the daily outrage of untimely death and dying (Rankine, 2015).

Rankine's characterisation of untimely death and horror as daily experiences for Black people in the United States evokes Mamie Till-Mobley's activism; in a similar way Deborah McDowell also grounds Mrs. Till-Mobley's political significance. As McDowell contends, Mrs. Till-Mobley established a 'tradition' of curating sites of witness for dead Black children. Such a 'tradition' involves '[seizing] the political stage [and] refusing to be relegated to roles as passive mourners' (McDowell, 199: 169). Advancing a similar view, Rankine writes:

Mobley's refusal to keep private grief private allowed a body that meant nothing to the criminal-justice system to stand as evidence. By placing both herself and her son's corpse in positions of refusal relative to the etiquette of grief, she 'disidentified' with the tradition of the lynched figure left out in public view as a warning to the black community, thereby using the lynching tradition against itself. The spectacle of the black body, in her hands, publicized the injustice mapped onto her son's corpse. (Rankine, 2015)

For Rankine, Mrs. Till-Mobley challenged the established 'looking relations' set within a white supremacist context of terror so that 'Black looks' actively '[looked] back, and at one another, naming what we see' (hooks, 1992: 95). Rankin contends that Mrs. Till-Mobley's revaluation and operationalising of 'Black looks' directly contributed to civil rights activism as it 'reframed mourning as a method of acknowledgement that helped energize' (Rankine, 2015) this movement for social change through embracing her son as its 'sacrificial lamb' (HudsonWeems, 1994: 95). As such, Mrs. Till-Mobley meticulously reads her world of racism and sexism in an effort to create a broader public audience for grieving her son. Establishing a relationship to beauty would prove critical to this effort.

In addition to the terrible odour that attended an encounter of Emmett's body after it was recovered from the Tallahatchie River on a hot Mississippi summer's day, he was gruesomely disfigured. As Mrs. Till-Mobley encountered her son for the first time in Ahmed Rayner's mortuary, she saw a 'large gash in his forehead,' an open mouth and protruding tongue; she noticed that his 'lips were twisted and his teeth were bared just like a snarling dog's'; in addition to a gunshot wound, an eye was missing, and she 'found that part of the ear was gone, and the entire back of the head had been knocked out' (Anderson, 2015: 55); and this was only the right side. The left side of Emmett's face 'looked as if somebody had taken a criss-cross knife and gone insane' (Anderson, 2015: 56). As Mrs. Till-Mobley decided to embrace her son as a 'sacrificial lamb,' she extended this Christian symbolism to ensure public witnesses at this symbolic crucifixion. Not only did she insist on an open-casket funeral, she allowed photographers to take pictures of the body and to have those images appear in national and local newspapers and magazines. In photographs of Emmett in his casket, one may also observe earlier photographs of him, as Devery Anderson writes, '[Mrs. Till-Mobley] taped photos from the [Christmas before] to the inside lid of the casket so that people could contrast the mutilated face before them to the handsome young man who was so full of life only a week earlier' (Anderson, 2015: 56). Thus, in addition to the work of 'reframing' that McDowell and Rankine identify, that speaks to the larger cultural expectation regarding the presentation of Black children in general, the intimate curatorial work that Mrs. Till-Mobley performed also speaks to her son's particular life and history. This dialectic between mine and ours, one mother's son and a community's representative, insists upon an intelligible beauty.

The great distance between Emmett's appearance in the before photographs and then how he looked after being brutalised and killed obscures the ugliness Milam and Bryant, Till's killers, initially saw in him. White supremacy insisted that Emmett was ugly and Mrs. Till-Mobley needed to challenge what they saw as fact; she needed to frame Emmett, within a discourse of beauty. In the introduction to her book Posing Beanty: African American Images from the 1890s to the Present, Deborah Willis cites Ben Arogundade who provocatively frames the subject of the moral and political implications of beauty:

in literary terms, Black beauty remains a cause without a portfolio [...] Who can really talk of the folly of beauty when there are still so many other battles to be won? But beauty is also a battle. And the right to be beautiful and to be acknowledged as such whoever you are, wherever you are from is not so much 
a folly as a human-rights issue. In writing the history of the black experience did we forget something important? Did we forget about beauty? (Arogundade in Willis, 2009: xv)

Beauty is a 'human-rights issue' because it is easier to kill people considered ugly. As Toni Morrison (2008) notes, white supremacist ideology has insisted on Black American ugliness. In reflecting on the historically peculiar fact of this insistence, she recalls a conversation that establishes a link between beauty and grief:

Once I heard a white man comment on the Vietnam War with much grief for the Vietnamese. He ended his brush with compassion by saying: 'It seems all the more horrible to me because they are such beautiful people.' His aesthetic sensibilities were outraged far more than his morals, it seemed. I was tempted then--and now--to believe that although this country was easily capable of annihilating a 'beautiful' people, the awareness of that beauty may very well have been a major cause of the subsequent national remorse. (Morrison, 2008: 47)

Morrison goes on to query the possibility of such grief emerging if the people 'looked like the Congolese' (Morrison, 2008: 47). As her reflections suggest, beauty informs how grief is acknowledged within a white supremacist context. Opening the casket and exhibiting her dead son seems insufficient for attracting appropriate support for her suffering; it did not make his life 'grievable' within mainstream U.S. culture: 'If a life is not grievable,' writes Judith Butler, 'it is not quite a life; it does qualify as a life and is not worth a note' (Butler, 2006: 34). So, where Emmett's beauty and humanity were not presumed, his mother underscored these aspects through the photographs she strategically arranged on the raised lid of his coffin. Evidence of beauty here gets deployed as a visual assertion of his life and humanity.

Another much discussed case for African American media and activists is the murder of Trayvon Martin. Trayvon was a very attractive young man, as emphasised in the mainstream press coverage following his killing. The earliest media images of him showed him with a closely cropped haircut, smiling or wearing an immaculately clean football uniform with an unblemished face, striving to scowl; it was a cliché of American Beauty. In a counternarrative move, journalists scoured social media to uncover photographs of Trayvon that undermined his claim to beauty and thus logically justified the killing. Thus, the boy who had been on the honour roll and volunteered, baby sat, and baked cookies began to be described in the mainstream media as someone who smoked marijuana and was depicted in photographs wearing gold grills on his teeth. This counter-narrative cast Trayvon as a thug (and thus, ostensibly, unattractive). Beyoncé intervenes in this narrative of ostensibly unattractive Black boys who deserve their intolerant, brutal fates - both indirectly and explicitly. Indirectly, the lyrics to Beyoncé's former pop group's (Destiny's Child) song 'Soldier' (2004) celebrates the glamour of a street, 'hood aesthetic that Trayvon was clearly experimenting with. The photographs of Trayvon Martin that came into mass circulation following speculation about his character reflects the allure of an urban, hip-hop aesthetic of desirability that Destiny's Child heralds in the song. Thus, just like the photograph of Trayvon trying to look like he was a tough, hard, football player show him trying on an image, the photographs of him with a grill as well as the ones with subdued eyes show him making an effort to be the 'chiefin' ' 'rude boy' with 'street credibility' celebrated in the song.

Scholar Michael Eric Dyson (2001) shares a perspective on famed, slain rapper Tupac Shakur that helps situate how Trayvon Martin may have been consciously framing his self-presentation. According to Dyson, Tupac was a thespian who found that his interest in the arts plagued his efforts to attract the attention of the girls who attended his high school. Thus, adolescent angst drove Tupac to adopt a thug persona because the 'bad boy' look contributed to his desire for popularity (Dyson, 2001: 76, 176, 200, 241-242). Dyson's story about Tupac's angst fills a gap in popular representations of heterosexual Black male adolescents and by extension, offers a way of interpreting Trayvon Martin's self-presentation that provides a motive for his behaviour beyond the presumption that he only lived as a violent gangster.

Beyoncé more explicitly enters the story of Black boys who are made ugly in American popular culture and die brutally for it, once the American criminal justice system fails to hold murderer George Zimmerman accountable for Trayvon Martin's death, in 2013. After Zimmerman's acquittal, Beyoncé appeared with her husband Jay Z at an activist vigil in New York City that called for an end to 'stand your ground laws' (Devereaux and Williams, 2013). This is a reference to US legislation that makes it lawful for lethal acts in the face of self-defence against a perceived threat. This legal context directly informed Zimmerman's acquittal; Beyoncé and Jay Z also appeared in a photograph with Trayvon's parents, Sybrina Fulton and Tracy Martin (Longo, 2013). By 2016, Beyoncé showcased an evolving and highly sophisticated understanding of the relationship between the past and the present when she invited the 'Mothers of the Movement' to be her guests at the VMAs on the anniversary of Emmett Till's death, and carefully styled them through an appeal to glamour. 


\section{GLAMOROUS CONTESTATION: AUTHORING GRIEF}

Poet Kevin Young (2012) recognises that unexpectedly, glamour serves Black artists in their political confrontations with racial atrocity. He offers jazz singer Billie Holiday's iconic performance of 'Strange Fruit' (1939) as an example of glamour making its unlikely appearance. The words of the song were first written as a poem by Abel Meeropol in 1936 under the title 'Bitter Fruit' (Margolick, 2001: 21). The poetry captures the sight and smell of a lynched Black body hanging from a tree. As cultural critic Hilton Als explains, during the 1930s and 1940s when Holiday sang the 'Strange Fruit' at the racially integrated night club Café Society in New York, she was doing something bold since the song 'tackled' racial hatred head-on at a time when protest music was all but unknown' (Margolick, 2001:3). Even if the progressive patrons present at Café Society wanted some reprieve from the weighty content chronicled in the song, Holiday's song styling and stage presence contributed to its appeal. Those present to see Holiday perform described an unforgettable experience. Songwriter Betty Comden remembered the experience as 'thrilling' (Margolick, 2001: 40). In Comden's estimation, 'Strange Fruit' was 'bloodcurdling and wonderful' no less because of the way Holiday styled the song and presented herself (Margolick, 2001: 40). As jazz writer Robert Gleason explains, Holiday was 'shocking in her personal magnetism,' which she accented with 'a gardenia in her hair' (Margolick, 2001: 40). Young suggests that Holiday's appeal to glamour in performing 'Strange Fruit' works because it communicates through a visual plane of desire and thus flirts with the eye. Thus, for Young, glamour tempts witness.

Stephen Gundle contends that glamour may be, 'best seen as an alluring image that is closely related to consumption' (2008: 6). Sharp feminist critique of Beyoncé challenges her self-professed claim to feminist politics for the very links to consumption that Gundle places at the centre of glamour's definition. bell hooks, perhaps one of Beyoncé's most prominent and consistent critics, finds that Beyoncé's claim to feminism fails to account for the ways in which her presentation of wealth colludes with capitalism and overlooks other structural forms of domination. Admitting that Beyoncé's Lemonade visual album (2016) 'positively exploits images of black female bodies,' (hooks, 2016), hooks contends that their glamorisation stops short of providing an alternative worldview rooted in structural change. Though Janet Mock (2016) criticises hooks for dismissing femme feminists and their ability to have complicated critiques of patriarchy whilst embracing hyper-feminised celebrations of identity, her position overlooks hooks's contention that freedom struggle roots out structures of domination.

Beyoncé best exploits glamour for the sake of freedom struggle when she acts on her understanding that 'there is power in looking' and uses such understanding to challenge white supremacy (hooks, 1992: 94). For hooks, the 'oppositional gaze' is developed in response to white supremacist efforts to dominate the Black gaze and thus punish Black people for looking. For hooks, the oppositional gaze becomes a form of agency whereby Black people seeks to 'change reality' through looking (1992: 94). Such forms of looking endeavour to interrogate, critique, discern, and generate an awareness of how whiteness as power operates and to document it (1992: 95). Thus, when hooks celebrates Lemonade for presenting 'a powerfully symbolic black sisterhood that resists invisibility' (hooks, 2016), she acknowledges the importance of Beyoncé's work in contesting 'the violent erasure of black womanhood' in popular culture (hooks, 1992: 119). For hooks, the problem with how Beyoncé asserts Black sisterhood is that it stops short of offering another model of seeing Black women once present (2016). For this reason, Beyoncé's live performances and award show attendances matter, because in these arenas, Beyoncé wields glamour to convey solidarity with Black mothers whose children were victims of murderous figures of state authority. While Lemonade features Beyoncé's alliance with these mothers, her appearance with them outside the frame contests the expectations of even these 'looking relations.'

Beyoncé, herself a meticulous, careful cultivator of self-image, paid homage to Mrs. Till-Mobley's call for beauty at the site of her grief when she invited the 'Mothers of the Movement' onto the 'red carpet,' and thus to a place where onlookers expect beauty to make an appearance. Though the VMA 'red carpet' was actually white in 2016, its culturally symbolic function was the same: to hail Hollywood stars as celebrity versions of royalty. In honour of the tradition believed to have begun when Clytemnestra rolled out 'the tinted splendours' upon Agamemnon's return home as a war hero, the red carpet pays homage to triumph and success (Baker, 2016). Here, celebrities and fans collude in staging tableaux; celebrities expect for people to stare at them and so arrive prepared to meet that expectation with highly stylised and alluring hair, makeup, and fashion. Throughout the tableau, Beyoncés staged glamour mingles unexpectedly with grief and remorse, featuring an array of Black girls and Black women who have been celebrated and ridiculed in staggering ways. From the mothers to the actresses and models, from Beyoncé to her daughter Blue Ivy, this group represents an entire spectrum of marginality within the event's context of glamour, making their experience of white supremacist violence visible in the name of beauty and excellence. So as ethereal as the sartorial styling of Beyoncé and her guests may initially appear, their challenges and losses reveal the deadly seriousness of difference at its furthest extremes. For example, on the non-lethal end of the spectrum, African American actresses and models Quvenzane Wallis, Winnie Harlow, and Ava Clarke all experienced and confronted public cruelty. Harlow's vitiligo and Clarke's albinism casts them as 'extraordinary bodies' and thus 
objects of enfreakment (Thomson, 1997). Quvenzane Wallis's experience of racism as a Black girl demonstrates how deviancy informs a reading of ostensibly 'normate' girls (Thomson, 1997: 8). In her case, the online magazine The Onion, known for their biting satire, apologised to Wallis after calling her a 'cunt' in a tweet during the 2013 Oscars where the then nine- year-old was nominated in the Best Actress category for her performance in Beasts of the Southern Wild (Ditum, 2013).

In addition to this blatant sexual objectification, Quvenzane Wallis was the target of racist trolls on Twitter for playing the starring role in Annie (2014) — in which Beyoncé's husband and Blue Ivy's father, Jay Z was one of the producers - met with the ire of fans of the original film who unleashed their contempt via social media against casting a Black girl in the role made iconic by a red haired White girl (Edwards, 2014). The Carters have experienced similar outrage with fans critical of their daughter's hair; in Blue Ivy's case, she has been the subject of intense outrage by mostly Black fans of her parents who dislike how the child's hair appears; some even started a Change.org petition demanding that the pair comb their daughter's hair (Wilson, 2014). While neither has responded in the press, they each have made statements through their music that might speak to the matter; in the video for 'Formation,' (2016) for example, Beyoncé sings that she likes her 'baby hair and afros' and in 'Picasso Baby,' (2013) Jay Z notes that haters even 'talk about your baby crazy.' While Genius.com, a website offering public annotations of rap lyrics, makes a specific link between Beyoncé and Blue's hair in 'Formation,' 'Picasso Baby,' which debuted before the petition, does not interpret the lyrics as a reference to her hair; instead, their interpretation suggests that Jay's lyrics reference rumours about the child being a product of an occult affiliation. ${ }^{3}$

Rather than as an array or a continuum of 'extraordinary bodies' accompanying the celebrity whose Lemonade visual album was nominated for eleven awards in six categories that evening, the news media focused their attention on the fact that Beyoncé and her guests were adorned in couture. Beyoncé wore Francesco Scognamiglio and fouryear-old Blue wore a dress from the Mischka Aoki luxury children's line. Breathless reports celebrated the $\$ 13$ million worth of Lorain Schwartz jewels Beyoncé wore, and were charmed that Blue Ivy complemented her $\$ 11,000$ gown with a pair of $\$ 595$ Giuseppe Zanotti sneakers (Michault, 2016). As staggering as these prices are, Beyoncé's guest list begs consideration for the knowing juxtaposition of the financial cost of these luxury goods set against the human cost Black mothers have historically paid through their children's blood; the Black mother and daughter whose luxury items may be celebrated is diametrically opposed to the Black mothers represented who are absent a child; all caught in a web of history that extorts the commodification of their toil and their wombs. While the 'pride of place' that these Mothers of the Movement also occupy in Lemonade comes across at the VMAs where they were 'dressed like royalty in shades of purple and champagne' (Francis, 2016), arguably, appearing with Beyoncé cost McSpadden, Carr, Johnson, and Fulton one son each. The fee exacted from these ordinary Black mothers, the other end of the social class spectrum of women in Beyoncés party, brings into ironic focus the exorbitant price they have paid without fanfare. Glamour and tragedy intersect here to set in relief the human toll extracted from Black mothers. If Beyoncé's relationship to 'black feminist surrogation' helps to make 'black female sociopolitial grief and loss palpable' through both the lyrics and music videos for her 2006 B'Day album (Brooks, 2008), the staging of her guest list to include these mothers at the VMAs ten years later expands the scope of her original work. This expansion recognises a longer narrative of suffering that Black mothers endured, on the very anniversary of Emmett Till's murder. A closer examination of the tableau that Beyoncé stages leads to an articulation of what can be called the Mamie Till-Mobley narrative of grief. This narrative offers an origin story of US Black mother's politicisation, and documents the challenges she confronts in pursuing justice.

As Mrs. Till-Mobley admitted, Emmett's death politicised her (Till-Mobley and Benson, 2003: 192). Prior to his death, she had not concerned herself with racial violence much, since it had not touched her life in such a personal way; Emmett's death changed that (Till-Mobley and Benson, 2003: 192). In providing a lens into Black women's mothering in the aftermath of tragedy, the Mamie Till-Mobley narrative of grief becomes a window into activist dimensions of mourning for Black mothers, making such civil rights widows visible. When Black women are at the centre of narratives of catastrophic loss, although glamour may seem alien to a consideration of grief, it can join together in such instances of public visibility. It is certainly a function of white supremacy to marginalise Black women from a general discourse of honour through grief. As a point of contrast, Jacqueline Kennedy's dignity after the death of JFK, has been heralded and entangled with discursive associations of Whiteness with youth, beauty, glamour, fashion, death and mourning. Recognition for a Mamie Till- Mobley narrative anticipates and informs Mrs. Kennedy's example alongside the civil rights widows occasionally discussed in the same terms (Margolick, 2018).

The adoring gaze that met Beyoncé and her guests on the VMA white carpet stands in stark contrast to the hostile glare that Mamie Till-Mobley met from white onlookers in Mississippi. Many White Mississipians felt chastised as a result of the attention they received from Mrs. Till-Mobley's decision to expose Emmett's body and with it, a harsh media glare that indicted the state for Bryant and Milam's crimes (Whitfield, 1991: 27-31). They felt the need to defend their way of life against the intrusion that Emmett's ostensible transgression represented, and

${ }^{3}$ See: https://genius.com/Jay-z-picasso-baby-lyrics

(C) 2019 by Author/s 
the trial further upheld. Stanley Nelson's documentary film, The Murder of Emmett Till (2003) features news footage of White townspeople castigating Mrs. Till- Mobley for offering up his gruesome body for public consumption, thereby ignoring the way that her decision perfectly mirrored decades of similar scenes that White lynchers turned into postcards and sent through the U.S. Mail (Allen, 2000). The criticism voiced in Mississippi was not new to Mrs. Till-Mobley - as she reports in her memoir, when a news bulletin interrupted the popular television comedy I Love Lucy to report that Emmett's body had been found, she received hate mail chastising her for this intrusion into popular white American everyday life (Till-Mobley and Benson, 2015: 130). By way of contrast, Ellen Fitzpatrick writes that when President Kennedy was assassinated, among the more than 1.5 million condolence letters sent to Mrs. Kennedy, there was 'an almost total absence of any letter or comment critical of the president' (2010: XXI). According to Fitzpatrick, 'those who despised the President found venues other than a condolence letter to express their sentiments' (2010: XXI); not so for Mrs. Till-Mobley. For her, condolence letters served as an outlet for white supremacist ire, such letters became a vehicle for hurling insults at grieving Black mothers and widows. Typically, one of the letters sent following the murder of Dr. Martin Luther King features at least one such example where the writer is particularly bitter because Mrs. King's comportment suggests dignity. 'Who do you think you are,' the anonymous writer asks, 'another Mrs. J. F. Kennedy? To me,' the writer continues, 'you were just another wig-covered burr head plotting more riots to carry on the black King's program.' ${ }^{4}$ Though Mrs King's loss was extraordinary, she remained an open target for offence.

Race also obscures some of the parallels that can be drawn between how highly visible American women have used their bodies to convey responses to catastrophic loss. For example, Jaqueline Kennedy echoes Mrs. TillMobley's call to witness. Thus, in the wake of her husband's assassination on November 22, 1963, Mrs. Kennedy refused to change out of her pink Chanel suit because she, 'wanted them to see what they've done' in killing the President (Horyn, 2013). In this instance, eight years following Mrs. Till-Mobley telling journalists that she wanted 'the world [to] see what they did to my boy' (quoted in Whitfield, 1991: 23) called for similar witness. Rather than make this comparison, Mrs. Kennedy relationship to grief is engaged through an emphasis on how fashionably elegant she appeared during the funeral for her husband. Self-presentation also figured prominently in media accounts of Mrs. Till-Mobley in mourning, but in her case, such concerns focused on her appearance following her son's funeral.

Mrs. Till-Mobley further stoked the ire of White Sumnor, Mississippi residents in how she dressed for court. According to the Nation newspaper reporter Dan Wakefield, when Mrs. Till- Mobley appeared in court wearing a 'gray flowered dress, a brown bolero jacket, a black hat, tortoiseshell glasses, and a gold watch,' her appearance was upsetting because 'she didn't fit the minstrel-show stereotype that most of Mississippi's white folks cherish' (Anderson, 2015: 124). Fashion served here as a vehicle for articulating Black subjectivity as it had been shaped within an affirming Black collectivity; this self-presentation as respectable enforced her appeal to justice as reasonable. Though Mrs. Till-Mobley was not a seasoned activist, her understanding of the importance of selfpresentation reflected the respectability politics that came to characterise the civil rights movement (a movement inspired by her fortitude and refusal to be cowed by racist disempowerment). Thus, as political scientist Jeanne Theoharis writes of Rosa Parks, 'there was a fixation on how she dressed' (2014: 85). On the day of her court hearing, Theoharis writes that Parks 'dressed carefully' and could recall every detail of what she wore because she 'well understood the importance of image to this protest, and she chose her outfit to reflect a dignified and proud citizenship, an in-your-face challenge to the degradation that segregation had long proffered' (2014: 88).

Sartorial style and activism emerges as an important consideration through the Mamie Till-Mobley narrative of grief as a way to provoke reflection on the role of money in conversation with socially prescribed race and gender roles. By heralding Mrs. Till-Mobley as a model of integrity and courage, this challenges some of the criticism that she received from prominent voices within Black political organisations soon after her son's murder. The National Association for the Advancement of Colored People (NAACP) President Roy Wilkens had grown weary of Mrs. Till-Mobley's requests for additional funds for her father and others who accompanied her to speaking engagements, held on behalf of the NAACP. Mrs. Till-Mobley and her Uncle Moses Wright were capable of drawing large crowds, which netted the NAACP great profits from the venues that offered advance fees as well as from the people who wanted to offer their financial support. Wilkens alleged that Mrs. Till-Mobley had become greedy and he fired her immediately after her impromptu shopping trip led her to miss a scheduled flight. In a recorded conversation, Wilkens tries to pin Mrs. Till-Mobley down in a disingenuous attempt to document her greed. Having accused Mrs. Till-Mobley of extorting money from her son's murder and in her alleged pursuit of fame, Wilkens even questioned the legitimacy of her grief, and further insulted her as a mother (Anderson, 2015: 204-207).

As an homage to Mamie Till-Mobley, Beyoncé's invitation to the 'Mothers of the Movement' on the anniversary of Emmett Till's death sets in relief the price of fame for Black mothers. Beyoncés deployment of glamour allows

\footnotetext{
${ }^{4}$ Taken from the Martin Luther King, Jr. Center for Nonviolence website: https://thekingcenter.org/archive/document/anonymous-lettermrs-king-following-mlks-assassination (Accessed 1 November 2018).
} 
Black civil rights mothers of murdered children and widows of martyred men to enter a discussion about white supremacy's insistence upon Black indignity and the eloquent ways that Black women have figured a response. Again, appearing with Beyoncé cost these mothers one son each. In the contemporary sense, these mothers are dressed in anticipation of fans who are expecting a celebratory scene. The activist position that these mothers now occupy would suggest a knowing confrontation between the expectations of that gaze and Beyoncé's attempt to show them confronting those expectations through their self-presentations of honour. In his engagement with the question of Mrs. Till-Mobley's request for money and dress, Devery Anderson's scholarship overlooks any motive beyond the one Wilkins advanced. In doing so, Anderson's work also ignores the friction that other individuals and organizations encountered regarding the fundraising actions of the NAACP. For example, as the Montgomery bus boycott extended throughout 1956, the Montgomery Improvement Association (MIA) came under financial strain through their local fund raising and turned their efforts towards a national audience (Theoharis, 2014: 126). The NAACP, which had not fully endorsed the boycott, questionably benefited from their fundraising efforts. Mrs. Parks was rare in her service as a speaker for the MIA in refraining from keeping an honorarium for her services. As Theoharis explains, when Parks spoke on behalf of the NAACP, she was paid $\$ 25$ per talk with the rest of the money split between the local and national branches (2014: 122). Though Mrs. Parks turned over all of her earnings, others viewed that money as 'compensation for their effort' (Theoharis, 2014: 122). Taking from the earnings suggests a strong critique of the fairness with which speakers were paid. This response was similar to longstanding practices that working-class Blacks employed where they responded to unfairly depressed wages by introducing informal methods of remuneration through a signifying practice that drew upon the moral economy (see also Kelley, 1996: 18-21). Ignoring this economic history in the case of Mrs. Till-Mobley proves problematic because it ignores the ways in which Black women can experience the intensification of the intersectionality of race, class and gender to further insult their grief.

White supremacist efforts to diminish Mrs. Till-Mobley's humanity were not limited to white people. Roy Wilkins, and by extension, the NAACP also insulted the integrity of her suffering and grief. To that end, the Mrs. Till-Mobley narrative of grief underscores the way that Black women's self-presentation can expose the agency of Black women in rejecting such insults. Through a consideration of how Black women dress for mourning, Black women's activism is directed towards achieving everyday justice and respect. Beyoncé draws attention to these intersections through her inclusion of her own daughter among her guests, as she was the target of intra-racial attacks about her appearance. Furthermore, the price of the garments that each of her guests wore also can be interpreted as symbolic of the inestimable cost of Black life for the Black sons who were killed, as well as the vicious attacks borne by the daughters who face racist assault.

One crucial component of Emmett Till's tragic fate is the way that hindsight underscores the fact that he stepped into an on-going history of national injustice that he most likely did not know or understand (Whitfield, 1991: 12). Not only was Till unaware of how the racial animus further peaked for Mississippi segregationists after the Brown v. Board of Education decision eroded legal protection for public school segregation, but he was probably unaware of the broader, longer history of disdain for Black boys in the American South. While it is certainly possible to cite the many names of those Black boys who died at the hands of white racists, we need to probe such unknowing in a broader, structural way that respects the injurious history but also explores its silencing. To that end, the intersection between Cathy Caruth's (1996) reading of Freud's efforts to think through the venomous persistence and insistence of European anti-Semitism, together with James Baldwin's (1985) reading of Christianity's legacy through the lens of U.S. racial history proves instructive. As Caruth details the mechanics of this association, the latency of the initial trauma helps explain the political conflict and antagonism expressed. As Freud would have it, Jewish history features an Oedipal repression of murderous feelings toward an authority/father figure, the matter of atonement in Christian and Jewish history unconsciously repeats such intent. Caruth writes, 'In belatedly atoning, as sons, for the father's murder, Christians feel Oedipal rivalry with their Jewish older brothers; a lingering castration anxiety, brought out by Jewish circumcision; and finally a complaint that the Jews will not admit the guilt that the Christians, in their recognition of Christ's death, have admitted' (1996: 18). Caruth explains that this belated Oedipal structure of unconscious wishes, reveals the way that Christian and Jewish history are inextricably bound to one another, revealing that the traumatic nature of history means that 'events are only historical to the extent that they implicate others' (1996: 18).

James Baldwin exchanges Freud's structure of consciousness for the structure of biblical narratives of slaughter and sacrifice, to arrive at a similar conclusion concerning U.S. racial history. In his reflections on the serial killing of Black children in Atlanta between 1979-1981, Baldwin offers that 'we all came here as candidates for the slaughter of the innocents' (1985: xv). Here, Baldwin is referring to King Herod's order to kill all male children under two-years old in the vicinity of Bethlehem, for the sake of preventing the rise of challengers to his throne, following a prophecy. The persistence of those intended for slaughter, for Baldwin, offers proof of the repetition of this biblical history of violence. The continued or repeated presence of this past contests the notion that History 
has been resolved and is over in any final sense for Baldwin; instead, it confirms our participation in historical cycles, which would include Jesus's crucifixion (the intended victim of King Herod's order).

As James H. Cone has noted, African American cultural workers have consistently drawn attention to the relationship between Jesus Christ and lynched Black bodies (2013: 93). As Cone writes, these cultural workers recognised 'that in the United States, the clearest image of the Crucified Christ was the figure of an innocent Black victim, dangling from a lynching tree' (2013: 93). Artist Renee Cox exemplifies this connection between Black bodies and the most powerful iconography in the Christian tradition through her Flipping the Script series, which was featured in an exhibition at the Brooklyn Museum in 2001. One of her paintings in this series, Yo Mama's Last Supper depicts a nude Cox and other Black figures re-staging Leonardo Di Vinci's The Last Supper, in response New York Mayor Rudolph Guiuliani claimed at the time he wanted 'decency standards' for New York City museums in receipt of government funds (Bumiller, 2001). Cox rebuked critics like Giuliani and the Catholic League President William Donahue for registering their offence - but avoiding expressing their offence for police brutality (Williams, 2001). The controversy had its roots in the way that Cox's 1990s work spoke directly to the on-going and notorious history of police brutality in New York. It Shall Be Named, a series of distorted photographs of a black man affixed to a cross, and Yo Mama's Pieta address directly the relationship between the crucifixion of Jesus Christ and the killing of unarmed Black people. Yo Mama's Pieta recasts Michaelangelo's famous Renaissance sculpture. Cox herself appears in the role of the Virgin mother and a male Black figure is in the role of Jesus. Placing a Black woman in the role of the Virgin Mary sets in relief the way that Black motherhood is implicated in the possibility of 'deliverance from the brutal legacy of slavery and white supremacy' [emphasis mine] (Cone, 2011: XV).

Mamie Till-Mobley's experience of loss, and her acceptance of the characterisation of Emmett as the 'sacrificial lamb' of the Movement, has influenced many scholars who have symbolically interpreted her in relationship to Mary, the mother of Christ (Baker-Fletcher, 2006: 149). The tableau that Beyoncé presented at the 2016 VMAs on the anniversary of Emmett Till's death and his mother's witness evokes this same narrative of religious witness. From the Italian designer she chose to design her gown, to the fourteen people total representing Beyoncé's group, an ethical call was staged. Further underscoring an intentional focus on motherhood and love, Beyoncé chose for the mothers a fashion designer for their attire who when asked 'who is the Francesco Scognamiglio woman,?' responded: 'My woman is a mother. My woman is a lover. My woman is a very sensitive and a very special person. And she is a woman who loves men. She knows how to love. She knows how to cry and she knows how to look chic, provocative and sweet at the same time' (Michault, 2016). Scognamiglio's response underscores the polysemic function of the mothers in Beyoncé's tableau who represented a multidimensional history of racial violence. Scognamiglio's description, (and by extention, Beyoncés presumed intent), also reflect evokes the Mamie TillMobley narrative iconic symbolism that Scholar and cultural critic Koritha Mitchell contends that the author BeBe Moore Campbell weds to her as a complete character in her fictive portrayal of Delotha, is also a character inspired by Mrs. Till-Mobley. As she writes, "Campbell succeeds in making Delotha a complete character who is both strong and vulnerable, forgiving and vengeful, maternal and sexual" (2012: 1050). Another layer of the ethical rhetoricism of the presence of these guests is also found in the legacy of the Petrarchan sonnet and its link to Emmett Till, given Marilyn Nelson's $A$ Wreath for Emmett Till, the book-length tribute to the murdered fourteenyear-old (2005). The fourteen people in Beyoncé's party were thus like a living Petrarchan sonnet - the eight/six arrangement has a call and response structure. Both forms, the fashion and the poetry, represent efforts towards remembrance and witness through culturally specific structure and form. One is a 'tiger's leap' into the past, while the other is recursive--a present that insists on it (Benjamin, 1968: 261).

\section{CONCLUSION}

Beyoncé knowingly invited the 'Mothers of the Movement' as a symbolic appreciation of the trajectory of bearing witness to mourning Black children that Mamie Till-Mobley established. Moreover, this established Beyoncé's role as acting in support of Black Lives Matter as a contemporary social justice movement that, as Rankine contends, 'aligns with the dead, continues the mourning and refuses the forgetting in front of all of us' (Rankine, 2015). In honouring Mrs. Till-Mobley on August 28, 2016, Beyoncé was paying homage to her understanding of what a white supremacist culture needed to see, in order to recognise and honour Emmett Till's humanity and that of the similarly dead and brutalised Black people whose killing remains in need of redress. Like Mrs. Till-Mobley before her, Beyoncés effort to curate an image of Black motherhood in mourning expands the terms of 'black feminist surrogation' to create a tableau through style and glamour that shifts the terms of Black hypervisibility to include dignified grief, and signal a call for a proper mourning of Black life. 


\section{REFERENCES}

Allen, J. (2000). Without Sanctuary: Lynching Photography in America. Santa Fe: Twin Palms.

Anderson, D. S. (2015). Emmett Till: The Murder That Shocked the World and Propelled the Civil Rights Movement. Jackson: University Press of Mississippi.

Anderson, E. (2013). Emmett and Trayvon. Washington Monthly. January/February.

Anonymous (1968). Letter to Coretta Scott King. Available at: http://www.thekingcenter.org/the-archives (Accessed 1 November 2018).

Baker, L. (2016). "Where Does the Red Carpet Come From?" BBC.com, 22 February. Available at: http://www.bbc.com/culture/story/20160222-where-does-the-red-carpet-come-from (Accessed 1 November 2018).

Baker-Fletcher, K. (2006). Dancing with God: The Trinity from a Womanist Perspective. St. Louis: MO: Chalice Press.

Baldwin, J. (1995). The Evidence of Things Not Seen. New York: Holt.

Benjamin, W. (Editor H. Arendt) (1968). Illuminations: Essays and Reflections. New York: Schocken.

Bosman, J. and Goldstein, J. (2014). Time for a Body: 4 Hours in the Middle of a Ferguson Street. The New York Times, 23 August. Available at: https://www.nytimes.com/2014/08/24/us/michael-brown-a-bodys-timeline4-hours-on-a-ferguson-street.html (Accessed 2 July 2019).

Brooks, D. A. (2008). “All That You Can't Leave Behind:” Black Female Soul Singing and the Politics of Surrogation in the Age of Catastrophe. Meridians: Feminism, Race, Transnationalism, 8(1), 180-204.

Bumiller, E. (2001). Affronted by Nude 'Last Supper,' Giuliana Calls for Decency Panel. The New York Times, 16 February. Available at: https://www.nytimes.com/2001/02/16/nyregion/affronted-by-nude-last-suppergiuliani-calls-for-decency-panel.html (Accessed 4 July 2019).

Butler, J. (2004). Precarious Life: The Power of Mourning and Violence. London: Verso.

Caruth, C. (1996). Unclaimed Experience: Trauma, Narrative, History. Baltimore: Johns Hopkins University Press.

Cobb, J. (2016). The Matter of Black Lives. New Yorker, 14 March. Available at: https://www.newyorker.com/magazine/2016/03/14/where-is-black-lives-matter-headed (Accessed 2 July 2019).

Cone, J. (2013). The Cross and the Lynching Tree. New York: Orbis.

Devereaux, R. and M. Williams (2013). Jay Z and Beyoncé Attend Trayvon Martin Protest in New York. The Guardian, 20 July. Available at: https://www.theguardian.com/world/2013/jul/20/jay-z-beyonce-trayvonmartin-new-york (Accessed 4 July 2019).

Ditum, S. (2013). The Onion's Apology for its Quvenzhané Wallis Tweet--Well, This is Awkward. The Guardian, 26 February. Available at: https://www.theguardian.com/commentisfree/2013/feb/26/onion-c-word-tweetquvenzhane-wallis (Accessed 4 July 2019).

Dyson, M. E. (2006). Holler if You Hear Me: Searching for Tupac Shakur. New York: Civitas Books.

Edwards, B. (2014). Annie's Black Now. Get Over It. The Root. 7 March. Available at: https:/ / kinja.com/api/profile/getsession?redirect $=$ https $\% 3 \mathrm{~A} \% 2 \mathrm{~F} \% 2 \mathrm{Fwww} \cdot$ theroot.com $\% 2 \mathrm{Fsetsession} \% 3 \mathrm{~F}$ r\%3Dhttps\%253A\%252F\%252Fwww.theroot.com\%252Fannie-s-black-now-get-over-it-1790874854

(Accessed 4 July 2019).

Ellison, R. (1995). Shadow and Act. New York: Vintage, Reissue.

Feldstein, R. (2000). Motherbood in Black and White: Race and Sex in American Liberalism, 1930-1965. Ithaca: Cornell University Press.

Fitzpatrick, E. (2010). Letters to Jackie: Condolences from a Grieving Nation. New York: HarperCollins.

Francis, A. (2016). Beyonce Brought the 'Mothers of the Movement' To the VMAs. HuffPost. 28 August. Available at: https://www.huffpost.com/entry/beyonce-vmas-black-lives-matter_n_57c38b66e4b085c1ff29e530 (Accessed 4 July 2019).

Gundle, S. (2008). Glamour: A History. New York: Oxford University Press.

Herstory (n.d.). Black Lives Matter Herstory. Available at: https://blacklivesmatter.com/about/herstory/ (Accessed on 2 July 2019).

Holloway, K. F. C. (2002). Passed On: African American Mourning Stories. Durham: Duke University Press. https://doi.org/10.1215/9780822385073

Hooks, B. (1992). Black Looks: Race and Representation. Boston: South End Press.

Hooks, B. (2016). Moving Beyond Pain. bell books Institute blog. 9 May 2016. Available at: http://www.bellhooksinstitute.com/blog/2016/5/9/moving-beyond-pain (Accessed 1 November, 2018).

Horyn, C. (2013). Jacqueline Kennedy's Smart Pink Suit, Preserved in Memory and Kept Out of View. The New York Times. 14, November. Available at: https://www.nytimes.com/2013/11/15/fashion/jacqueline-kennedys -smart-pink-suit-preserved-in-memory-and-kept-out-of-view.html (Accessed 1 November 2018.)

Hudson-Weems, C. (2006). Emmett Till: The Sacrificial Lamb of the Civil Rights Movement. Troy, Michigan: Bedford. 
Kelley, R. D.G. (1996). Race Rebels: Culture, Politics, and the Black Working Class. New York: Free Press.

Kelley, R. D.G. (2000). Slangin' Rocks...Palestinian Style: Dispatches from the Occupied Zones of North America in Jill Nelson (ed), Police Brutality: An Anthology. New York: W. W. Norton and Company.

Longo, D. (2013). Beyoncé, Jay Z Attend Trayvon Martin Rally in New York City. Latin Times. 22 July. Available at: https://www.latintimes.com/beyonce-jay-z-attend-trayvon-martin-rally-new-york-city-129545 (Accessed 4 July 2019).

Lowery, W. (2017). Black Lives Matter: Birth of a Movement. The Guardian, 28 November. https://www.theguardian.com/us-news/2017/jan/17/black-lives-matter-birth-of-a-movement (Accessed 2 July 2019).

Lowery, W. (2019). 'I Can't Breathe': Five Years After Eric Garner Died in Struggle with New York Police, Resolution Still Elusive. The Washington Post, 13 June 2019. Available at: https://www.washingtonpost.com/ national/i-cant-breathe-five-years-after-eric-garner-died-in-struggle-with-new-york-police-resolution-stillelusive/2019/06/13/23d7fad8-78f5-11e9-bd25-c989555e7766_story.html?utm_term=.1bb8f8c4e1ba (Accessed 2 July 2019).

Margolick, D. (2001). Strange Fruit: The Biography of a Song. New York: Ecco.

Margolick, D. (2018). Robert F. Kennedy's Final Flight: The Storied Journey of the Ride from California to New York. Washington Post, 3 June. Available at: https://www.washingtonpost.com/lifestyle/robert-f-kennedysfinal-flight-the-storied-journey-of-the-ride-from-california-to-new-york/2018/06/03/b312c440-66a3-11e8-a7 68-ed043e33f1dc_story.html?utm_term=.07f37f305ef6 (Accessed 4 July 2019).

McDowell, D. E. (1999), Viewing the Remains: A Polemic on Death, Spectacle, the [Black] Family in ed. Marianne Hirsch, The Familial Gaze. Hanover, New Hampshire: University Press of New England.

McGahan, M. (2016). Who Did Beyonce Bring to the 2016 VMAs? the Women with Her on the Red Carpet are Familiar to Lemonade Fans. Bustle, 28 August. Available at: https://www.bustle.com/articles/181102-who-didbeyonce-bring-to-the-2016-vmas-the-women-with-her-on-the-red-carpet (Accessed 1 November 2018)

McKinley, J. (2010). Officer Guilty in Killing that Inflamed Oakland. The New York. Times, 8 July. Available at: https://www.nytimes.com/2010/07/09/us/09verdict.html (Accessed 2 July 2019).

Michault, J. (2016). Who is the Designer behind the Dress Beyonce Wore to the MTV VMAs? 29 August, Antidote. Available at: http://magazineantidote.com/english/beyonce-francesco-scognamiglio-dress-mtv-vmalemonade-blue-ivy/ (Accessed 1 November 2018).

Mitchell, K. (2008). Mamie Bradley's Unbearable Burden: Sexual and Aesthetic Politics in BeBe Moore Campbell's Your Blues Ain't Like Mine. Callaloo, 31(4), 1048-1067. https://doi.org/10.1353/cal.0.0244

Mock, J. (2016). Response to bell books Facebook post. 9 May. Available at: https://www.facebook.com/janetmock/posts/10154228113096522/ (Accessed 4 July 2019).

Morrison, T. (1974). It is Like Growing up Black One More Time. The New York Times. 11 August. Available at: https:/ /www.nytimes.com/1974/08/11/archives/rediscovering-black-history-it-is-like-growing-up-black-one -more.html (Accessed 4 July 2019).

Nelson, M. (2009). A Wreath for Emmett Till. Boston: Houghton Mifflin Harcourt.

Nelson, S. (2003). The Murder of Emmett Till. American Experience, PBS, 2003.

Rankine, C. (2015). The Condition of Black Life is One of Mourning. The New York Times. 22 June Available at: https:/ /www.nytimes.com/2015/06/22/magazine/the-condition-of-black-life-is-one-of-mourning.html (Accessed 1 November 2018).

Somashekhar, S. and K. Kelly (2014). Was Michael Brown Surrendering or Advancing to Attack Officer Darren Wilson? The W ashington Post. 29 November. Available at: https://www.washingtonpost.com/politics/2014/11/ 29/b99ef7a8-75d3-11e4-a755-e32227229e7b_story.html?utm_term=.8e813505a4a5 (Accessed 2 July 2019).

Theoharis, J. (2014). The Rebellious Life of Mrs. Rosa Parks. Boston: Beacon Press.

Thomson, R. G. (1997). Extraordinary Bodies: Figuring Physical Disability in American Culture and Literature. New York: Columbia University Press.

Till-Mobley, M. with Benson, C. (2004). Death of Innocence: The Story of the Hate Crime that Changed America. New York: Random House.

Tyson, T. (2017). The Blood of Emmett Till. New York: Simon \& Schuster.

Whitfield, S. (1991). A Death in the Delta. Baltimore: Johns Hopkins University Press.

Wilkerson, I. (2016). Emmett Till and Tamir Rice, Sons of the Great Migration. The New York Times, 12 February. Available at: https://www.nytimes.com/2016/02/14/opinion/sunday/emmett-till-and-tamir-rice-sons-of-the -great-migration.html (Accessed 4 July 2019).

Williams, M. (2001). 'Yo Mama' Artist Takes On Catholic Critic. The New York Times, 21 February. Available at: https://www.nytimes.com/2001/02/21/nyregion/yo-mama-artist-takes-on-catholic-critic.html (Accessed 4 July 2019.)

Willis, D. (2009). Posing Beauty: African American Images from the 1890s to the Present. New York: W.W. Norton. 
Wilson, J. (2014). Blue Ivy's Hair Sparks Ridiculous Change.Org Petition, and We're Disgusted. HuffPost. 11 June. Available at: https:/ / www.huffpost.com/entry/blue-ivy-petition-comb-her-hair_n_5483765?guccounter=1\&g uce_referrer=aHR0cHM6Ly93d3cuZ29vZ2xlLmNvbS8\&guce_referrer_sig=AQAAAABmDOc8HUw4ahR Fvt8JUyQKONkO1CSTnq716ZPb9Xpfarf5LRqULVIwUa-smhjkQSo3PxFMhsB6VvTxw7UhrjBk47vGknQ pwd3ZHB_H0tDuE5aKA4Sc8O4aX1BR9HmnxI6e2kgnZxD44R1M-24aIumh5RORi8sXMnGy9gmd7Cmp (Accessed 4 July 2019).

Young, K. (2012). The Gray Album: On the Blackness of Blackness. Minneapolis, Minnesota: Graywolf Press.

Citation: Hite, M. S. (2019). Beyoncé, Black Motherhood, and the Return of Wrenching Times. Feminist Encounters: A Journal of Critical Studies in Culture and Politics, 3(1-2), 03. https://doi.org/10.20897/femenc/5909

Copyright (C) 2019 by Author/s and Licensed by Lectito BV, Netherlands. This is an open access article distributed under the Creative Commons Attribution License which permits unrestricted use, distribution, and reproduction in any medium, provided the original work is properly cited. 